International Journal of Linguistics, Literature and Translation (IJLLT)

ISSN: 2617-0299 (Online); ISSN: 2708-0099 (Print)

DOI: $10.32996 / \mathrm{ijllt}$

Journal Homepage: www.al-kindipublisher.com/index.php/ijllt

IJLLT

\title{
A Critical Analysis of the Post-structuralist Thought with Reference to 'The Death of the Author' by Roland Barthes
}

Ashis Biswas

Assistant Professor, Bamanpukur Humayun Kabir Mahavidyalaya, India

Corresponding Author: Ashis Biswas, E-mail: biswasashis75@gmail.com

\section{ARTICLE INFORMATION}

Received: November 03, 2020

Accepted: January 17, 2021

Volume: 4

Issue: 1

DOI: $10.32996 /$ ijllt.2021.4.1.18

\section{KEYWORDS}

Roland Barthes, Death of the Author, Post-structuralism, Deconstruction, Marxism, Postenlightenment

\section{ABSTRACT}

Roland Barthes in his famous essay "The Death of the Author" from a poststructuralist position took a stand against the notion of authority in a text. He while referring to the myth of Sarrasine in Balzac asks certain essential question regarding the position of authorship. For him the author only is a participant in the existing discourse of the time-a mere explorer of the existing symbols and pre-existing linguistic and literary systems. One the other hand he only narrates the events through the existing codes but never participates in it. It is here where Barthes connotes that the author might be praised for his mastery over the existing codes but not for his genius. Likewise, Barthes explores various concepts of post-enlightenment to give his concept of the death of the author not in a literary sense where the work is found importance rather than the author who is the product of the industrial strategy and his position changes over time according to the changes in society.

"The Death of the Author" is, perhaps, the first essay on Post-structuralist discourse. However, it was, at first, delivered as a lecture at Johns Hopkins University in 1967 by the French literary theorist Roland Barthes (1915-80). The essay was later included in the collection of essays Image, Music, Text published in the following year after a more important seminal work, Writing Degree Zero which contains the initial information on Post-structural linguistics of 1960s; it is here that Barthes anticipates the concept of text and authority in the most straight-line perspective. Though the Leftist ideology and doctrine had much influence on the literary journey of the time, as was evident in the avant garde' literary magazine The Tel Quel, Barthes was not a typical Maxist; even though in his writings he was trying to explore the myth of authority in terms of the cultural myth of subjectivity, a post-Enlightenment phenomenon- a celebration of individuality. Therefore, in this context The Death of the Author as a challenge to the humanist ideas of the $19^{\text {th }}$ century becomes very much significant.

Barthes uses the myth of Sarrasine by Balzac to subvert the notion of authority, especially that of a writer over a text. The castrato, La Zambinella who is praised for his essential female qualities: "....her sudden fears, her irrational whims, her instinctive worries, her impetus boldness, her fussing, and her delicious sensibilities" (Rice 118), becomes the pinnacle of argument for Barthes; and he continues with few questions regarding the origin of this statement: "Who is speaking thus? Is it the hero of the story bent on remaining ignorant of the castrato hidden beneath the woman? Is it Balzac the individual, furnished by personal experience with a philosophy of woman? Is it Balzac the author professing 'literary' ideas of feminity? Is it universal wisdom? Romantic psychology?" (Rice 118). These questions affirm that La Zambinella is a stereotype of woman the way Balzac describes her. But Barthes raises question against Balzac's claim as an originator, and argues in favour of his famous assertion that Balzac is not, here, the author but is merely describing the component of the discourse of the nature of womanhood. So, Balzac shares the philosophy of keeping with the western discourse as is found in Petrarch's Laura. Therefore, writing is a destruction of "every voice, every point of origin" (Rice 118) including the presence of an authorial voice.

In the common view of things, to the common reader the piece of writing is so much associated with the writer, especially in the case of literary writing that it has almost become psychological that we cannot dissociate the author from the writing, so much so that we make substitution of the text with the author. In Areopagitica (1644) we assume that Milton expresses political

K C AL-KINDI CENTER R D FOR RESEARCH AND R D DEVELOPMENT Your gateway to world-class research

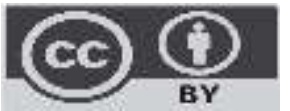

Published by Al-Kindi Center for Research and Development. Copyright (c) the author(s). This open access article is distributed under a Creative Commons Attribution (CC-BY) 4.0 license 
opinion, but for Barthes what Milton writes in there is the continuity of the discourse of freedom which is already known to the writers/thinkers of the Restoration. French structuralist critics also sees a text as impersonal- a manifestation of the social

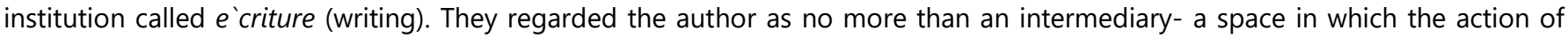
writing precipitates the elements and codes of the pre-existing linguistic and literary system into a particular text.

A literary text, however, does not refer to reality; it is non-referent, as Barthes points out in one of his essays From Work to Text: in a text all the "incidents are half-identifiable: they come from codes which are known but their combination is unique, founding the stroll in a difference repeatable only as difference." (Rice 194). Therefore the meaning in a literary text is basically intransitive in nature. The artifice of non-referential 'textuality', i.e., the fact or episode in a literary text, are made to seem vraisemblable (credible) by being brought into accord with the modes of discourse and cultural stereotypes, e.g., Blake's Sunflower is a symbol of whatever there is in heaven, which, however, cannot be transcend to real sunflower. Literature is merely the practice of these symbols themselves. These symbols are not arbitrary in nature, but part of a discourse of meanings, e.g., when Spenser depicts the Red-cross Knight, the name symbolizes the very notion of Christ. For a literatia or an artist who practices this symbolism, knows very well that he cannot invent new symbols; it conventionally and stereotypically belongs to the accumulated series of meanings of that discourse. So the narrative reveals the fact that the author is not necessarily the creator of symbols. It is in this sense that the author dies and writing begins, the idea of which is so artistically and rhetorically aligned by the French scholar rightly going with the cultural heritage of eccentricity of their intellect. On the other hand, writing implies the effacement of intention, as the author does not participate in the event; it is such a thing that it is like death, as Rabindranath Tagore as a poet states in his autobiography, Atmaparichay (Of Myself): "I started drawing, started painting; I never knew the next carve along which my brush will move" (My translation) (Tagore 4-5)

In this context, Barthes refers to the ethnographic society where any person can never assume the authority of writing. Here the person writes a narrative act as a medium, implying his performance (not creativity) only as a relater. Barthes says that the performer of the act of writing might be admired or praised for his/her mastery over the existing codes "but never his genius". So, here, Barthes is focusing on the post-Enlightenment concept of the 'genius'. Horace in his Ars Poetica refers to a competent literary author variously as scriptor (writer), poeta (maker), and carminis auctor (originator of a poem) who must possess a natural talent or genius (ingenium).

Barthes' assertion that author is the creation of the Modern age, can be drawn parallel to the concept of the sociologist Max Weber who identifies the ground of individualism in the Modern age with the rise of capitalism that promoted individualism by definition. Therefore, the notion of authorship is more of a post-feudal phenomenon. The concept of genius figure in the philosophical writings of the late $18^{\text {th }}$ century can be found in the German idealists like Kant, Hegel, and others. Germany also symbolizes the growth of Protestantism. The Protestant churches founded there advocated the liberation of the individuals and free will. Therefore, there are two sources of the concept of genius, viz., Protestantism and $19^{\text {th }}$ century economy with the rise of capitalism. The later concept of the valorization of authorship, however, goes with the New Historicist conception: the authorship to be a cultural construct that emerged and changed in accordance with changing socio-economic condition, and institutional arrangement for the writing and distribution of books over many decades in the Western world. A blooming literary market resulted in the writers' appealing for copyright laws. This condition of the literary market place fostered the claims by writers that they possessed originality, creativity, and genus; therefore, it was necessary to establish the ownership of such productions of their genius as their 'intellectual' as well as 'material property' (printed text).

Jean-Francois Lyotard in his book La condition postmoderne: repport sur le savoir (1979; The Postmodern Condition, 1984), while speaking of narrative, defines the word 'modern' by deriving from Latin modo meaning 'to be fashioned'. Barthes' pronouncement is somewhat similar to that of Lyotard: "a product of our society in so-far as, emerging from the Middle Ages and English empiricism, French rationalism and the personal faith in the reformation" (Rice 119), all of whom prefer to speak of man as human essence, i.e., being- the subjective notion. There is, however, no concept of human subject in reality. Therefore, the author being a subject carries no meaning, i.e., he is non-referent. Nevertheless, the author is still the authority and assumes responsibility for his action; and as confederate subjectivists we are, therefore, trying to accumulate data about the author to get a 'vivid idea' of the text which often seems to be a kind of Carlylean form of human worship. So it shows that we cannot free our perception from the tyranny of the author, not even in the form of criticism which, Barthes catalogued, is the failure of the $20^{\text {th }}$ century criticism. Baudlaire, Van Gogh for their tenets is listed by Barthes as the man/narrator who are considered to be more important that the instance of writing.

Barthes explains the idea of the death of the author via a specific French literary tradition, viz., that of Mallarme' and Valery. Mallarme's poetics consists in suppressing the author in the interest of writing; he writes of the poet's role being to "cede the initiative to words". Likewise, the narrative mode applied by the surrealists expressed a revolt against the control over the artistic process by forethought and intention, in favour of instance writing. Barthes also says that the 'I', i.e., the subjective self of the 
author is nothing but an instance. This act of saying ' $I$ ' is a moment- an event of time. This ' $I$ ', therefore, is a substance participating in a speech-act having components of shared meaning, i.e., a component of discourse. The Post-structuralist theorists re-described it as an it as an 'effect' or 'function' engendered by the internal play of textual language. This language is essentially defined by emptiness- a phenomenon that occurs by itself. Therefore, the ontological certitude of being associated with the author figure has been rejected. There is no author but only language.

For Barthes, writing is a gift like that from the muses in the western discourse, or as in Sanskrit terminology the concept of 'prasad' meaning blessings, and style or quality; in Sanskrit aesthetics it also means 'taste'. Therefore, the writer/poet is a master craftsman of writing; but the discourse that influences this writing is not subject to his feelings. i.e., he is only transcribing what is already there in the continuous discourse of language which is explicable only through language itself, i.e., signs which is indefinite: the immense dichotomy that Barthes refers here, goes with this realization of the forte' of the eternity of that processthe very concept of the play of signification that is later noted in the Derridian concept of Deconstruction. The book or the text is therefore a mere imitation- a repetition of signs over the ages whose origin is lost. Therefore, the meaning of the text of those signs only defers from the source; the same idea is recurred in Barthes' another essay, From Work to Text expressed by the term 'deferred action' (Rice 194).

Therefore, when the author (the origin) is removed, there only remains the text whose heart is not required to excavate, because it is dark; there is no finality of meaning but 'stereographic plurality' (Rice 194) a term that occurs in, From Work to Text. Barthes describes the author as a figure invented by the critical discourses in order to set limits to the inherent free play of meaning in reading a literary text. A somewhat similar conception is proposed by Derrida in his theory of the 'centre'. This 'centre' implies the authorial figure that upholds a meaning which ends somewhere; and thereby closes the play of signification. This assumption of the singular meaning is termed by Derrida as the 'intentional fallacy', e.g., the autobiographical interpretations. For Derrida, as for Barthes, a text has multiple meanings that imply play. Therefore, this idea of the 'plurality of meaning' (Rice 194) (a term occurred in From Work to Text) overthrows the notion of the 'ultimate meaning' or the 'transcendental signified' (Spivak 20) (coined by Derrida); thereby subverts the subjective notion God or the first cause that gives birth to the causality of structure, i.e., reason, science, law.

Barthes attacks the common and traditional view of the text as the ultimate explanation of the author; this, obliquely, implies the fact that the reader has the prime source of power in a text: the reader is not merely a hypothesis as the author is. The author is a convenient call-all for the critics, whereas the reader is at liberty to see the plurality of the text; in this context, Barthes refers to the ambiguous nature of Greek Tragedies, the duplicity of their meaning can be understood only by the reader. A text is a 'tissue of quotation'- a system of signs, viz., language: therefore, when writing, the author has to submit to this sign system, and might lose his individuality. So, it is the discourse that conditions the writing of text by means of language system. The author has to derive the argument of signification from the discourse; thereby the authorial intention is minimized. Therefore Barthes encourages the mode of reading that opens the text to an endless play of alternative meanings: "....a text is made of multiple writings, drawn from many cultures and entering into mutual relations of dialogue, parody, and contestation". This argument of Barthes is somewhat similar to that of Julia Kristeva's notion of any text being an 'inter-text'. The reader being part of this same discourse becomes the space where the collaboration of multiplicity- the various traces from the entire discourse occurs; Barthes addresses the issue also in From Work to Text: The reader is "someone at the loose end..., what he perceives is multiple, irreducible, coming from a disconnected, heterogeneous variety of substances and perspectives." (Rice 194)

Therefore, if we are to give importance to the process of reading, we must acknowledge that the singular authorial voice including his mood, passion, emotion, and ideology is no longer important, but the way language- the continuous chain of signifiers and discourse functions. Therefore, Barthes celebrates in his concluding lines the birth of the reader which implies the prioritization of the reading process in criticism to achieve multiple interpretations, thereby suggesting the ultimate erasure of the original intention, i.e., the death of the author.

\section{References}

[1] Rice, P., \& Waugh, P. (Eds.). (2001). Modern literary theory: A reader. Oxford University Press.

[2] Spivak, G. (1997). Of Grammatology, By Jacques Derrida. The John Hopkins UP.

[3] Tagore, R. (1352). Atmaparichay (Of Mayself). Vishwabharati Granthalaya. 